\title{
Perlindungan Hukum Terhadap Perempuan Korban Kekerasan Secara Verbal (Catcalling)
}

\author{
Anggreany Haryani Putri ${ }^{1}$, Dwi Seno Wijanarko ${ }^{2}$ \\ ${ }^{12}$ Fakultas Hukum, Universitas Bhayangkara Jakarta Raya \\ e-mail : anggreany.haryani@dsn.ubharajaya.ac.id; dwi.seno@dsn.ubharajaya.ac.id
}

Article info

Received: Apr 19, $2021 \quad$ Revised: May 14, $2021 \quad$ Accepted: May 22, $2021 \quad$ Published: Jun 10, 2021

DOI: https://doi.org/10.31599/krtha.v15i1.594

Keywords : Catcalling, Legal Protection

\begin{abstract}
In fact, bumans are social beings who coexist or work with others to build and synergize together. Building a social relationship must be a communication and behavior pattern towards others $A$ social relationship can be formed through communication and a pattern of good behavior, in establishing a communication with others in the future someone must throw a word containing elements of greeting or praise this is done with the aim of making communication become more familiar and tend not to be rigid. In some cases, these words or compliments often tend to be sexually nuanced such as whistling, praise that should not be appropriate to say, winks, or other things related. Sometimes and unwittingly it is in the pattern of behavior of society is considered ordinary when such behavior is one form of harassment which is then referred to as Catcalling. When viewed from the side of the Law on Child protection and Women catcalling behavior is an abuse because the victim feels harassed so that it feels, uncomfortable, disturbed, even terrorized by the behavior. Catcalling perpetrators can be ensnared by criminal penalties by Undang-Undang (UU) or by the Kitab Undang-Undang Hukum Pidana (KUHP)
\end{abstract}

Kata kunci : Kekerasan Secara Verbal, Perlindungan Hukum

Abstrak : Pada hakikatnya, manusia merupakan makhluk sosial yang hidup berdampingan atau bekerja sama dengan orang lain untuk membangun dan bersinergi bersama. Membangun suatu hubungan sosial harus adanya atu komunikasi dan pola tingkah laku terhadap sesama Suatu hubungan sosial dapat terbentuk melalui komunikasi dan pola tingkah laku yang baik, dalam menjalin suatu komunikasi dengan orang lain pada umunya seseorang pasti melontarkan suatuperkataan yang mengandung unsur sapaan atau pujian hal ini dilakukan dengan tujuan membuat komunikasi menjadi semakin akrab dan cenderung tidak kaku. Dalam beberapa hal seperti ini kerapkali ucapan atau pujian yang dilontarkan tersebut cenderung kearah hal yang bernuansa seksual seperi siulan, pujian yang seharusnya tak pantas diucapkan, kedipan mata, atau hal lain yang berkaitan. Terkadang dan tanpa disadari hal tersebut dalam pola prilaku masyarakat dianggap biasa saja padahal perilaku semacam itu merupakan salah satu bentuk pelecehan yang kemudian disebut dengan catcalling. Jika memandang dari sisi Hukum Perlindungan Anak dan Perempuan perilaku catcalling merupakan suatu pelecehan sebab si korban merasa dilecehkan sehingga merasa, tak nyaman, terganggu, bahkan terteror dengan perilaku tersebut. Pelaku catcalling bisa dijerat dengan hukuman pidana secara Undang- Undang maupun dengan Kitab Undang-Undang Hukum Pidana (KUHP) 
KRTHA BHAYANGKARA | Volume 15 Number 1, June 2021

\section{PENDAHULUAN}

Pada dasarnya setiap tindakan kekerasan adalah perbuatan yang tidak baik dan bahkan dilarang, hal ini dikarenakan tindakan kekerasan dapat menyebabkan berbagai akibat atau efek sampingmulai dari trauma, cedera berat, tidak mampu menjalankan tugas sehari-hari, pingsan, luka berat, kekerasan seksual, kehilangan panca indera mendapatkan cacat hingga kematian. Perlindungan terhadap anak dan perempuan telah diatur didalam UU No. 23 Tahun 2002 Tentang Perlindungan Anak jo UUD RI pasal 28 B ayat 2 dan Perpres RI No. 18 Tahun 2014 Tentang Perlindungan dan pemberdayaan perempuan dan anak dalam konflik sosial pasal 1 ayat 5 . Kekerasan verbal merupakan kekerasan tanpa menyentuh fisik tetapi membuat korbanmerasa ketidaknyamanan.

Pengertian tentang kekerasan yang termasuk kedalam golongan verbal adalah Kekerasan yang cara dilakukannya dengan berupa perilaku verbal di mana pelaku melakukan pola komunikasi yang berisi penghinaan, ataupun kata-kata yang melecehkan. Pelaku biasanya melakukan tindakan mental abuse, menyalahkan, atau juga merendahkan. Kekerasan verbal yang terjadi banyak dilakukan tanpa sadar atau tidak disengaja. Hal ini terjadidisebabkan orang-orang terkadang tidak menyadari bahwa apa yang dilakukannya adalah kekerasan karena menganggap hal itu sudah biasa dan sebatas gurauan semata. Kekerasan verbal tidak berdampak pada kerusakan fisik, tetapi berakibat pada luka psikis bagi korbannya. Oleh sebab itu, kekerasan verbal ini sering digolongkan juga pada kekerasan psikologis (psychological violence). Kekerasan verbal dapat menyebabkan ketidakstabilan suasana psikologis bagi penerimanya, seperti takut, kecewa, rendah diri, minder, patah hati, frustrasi, tertekan (stress), sakit hati, murung, apatis, tidak peduli, bingung, malu, benci, dendam, ekstrem, radikal, agresif, marah, depresi, gila, dan sebagainya ${ }^{1}$.

Dari penjelasan di atas maka muncul beberapa permasasalahan yaitu: (1). Bagaimana penegakan hukum terhadap pelaku tindak pidana kekerasan verbal (Catcalling) di Indonesia? (2). Bagaimana perlindungan hukum terhadap korban dalam tindak pidana kekerasan verbal (Catcalling)?

\section{METODE PENELITIAN}

Metode yang digunakan dalam penelitian ini adalah dengan pendekatan yuridis normatif yaitu dengan melakukan penelitian berdasarkan pada bahan-bahan hukum/referensi

${ }^{1}$ Wenny Wijayanti, Agustinus Djokowidodo, Persepsi Peserta Didik Terhadap Kekerasan Verbal oleh Guru diSMP se-Kota Madiun, Vol 2, Nomor 2 November 2019, Hlm. 81-98. 
dengan cara menelaah teori-teori dan konsep-konsep dari bahan-bahan hukum tersebut, yang berkaitan dengan asas-asas hukum peraturan perundang-undangan yang berhubungan dengan penulisan/penelitian ini.

\section{PEMBAHASAN}

Komnas Perempuan mengartikan catcalling sebagai salah satu bentuk pelecehan seksual dalam bentuk kekerasan verbal atau kekerasan psikis. Perilaku catcalling ini kerap kali dilakukan oleh laki-laki terhadap anak dan/atau perempuan dan hal yang mendasari tindakan atau perilaku ini adalah karena dorongan seksual. Perbuatan catcalling dapat berupa ucapan, komentar, siulan, atau pujian yang melecehkan, kadang-kadang disertai kedipan mata atau gerakan lainnya yang cenderung membuat tidak nyaman korban.

Tindakan catcalling dapat diancam hukuman pidana apabila telah memenuhi unsur pidana Pasal281 KUHP yang berbunyi “diancam dengan pidana penjara paling lama dua tahun delapan bulan atau pidana denda paling banyak empat ribu lima ratus rupiah:

1) Barang siapa dengan sengaja dan terbuka melanggar kesusilaan;

2) Barang siapa dengan sengaja dan di depan orang lain yang ada di situ bertentangan dengan kehendaknya, melanggar kesusilaan.

Menurut Pasal 281 ayat (2) ini, jika seseorang yang melakukan suatu perbuatan asusila tanpa persetujuan dari orang tersebut di depan orang lain, maka pelaku dapat dipenjara atau dikenakan denda. Selain itu di dalam Undang-Undang No. 4 Tahun 2008 tentang Pornografi ada beberapa pasal yang bisa digunakan sebagai dasar hukum dalam kasus catcalling, yaitu: Pasal 1 angka 1"Pornografi adalah gambar, sketsa, ilustrasi, foto, tulisan, suara, bunyi, gambar bergerak, animasi, kartun, percakapan, gerak tubuh, atau bentuk pesan lainnya melalui berbagai bentuk media komunikasi dan/atau pertunjukan di muka umum, yang memuat kecabulan atau eksploitasi seksual yang melanggar norma kesusilaan dalam masyarakat". Berdasarkan penjelasan tersebut catcalling bisa dianggap sebagai pornografi karena memenuhi unsur yangdisebutkan di atas, yaitu bunyi, gerak tubuh, suara, dan pesan yang memuat kecabulan.

Pasal 9 Undang-Undang No. 4 Tahun 2008 menjelaskan, “Setiap orang dilarang menjadikan orang lain sebagai objek atau model yang mengandung muatan pornografi." Dalam pasal 9 dalam Undang-Undang No. 4 Tahun 2008 tertulis jelas bahwa setiap orang dilarang menjadikan orang lain objek atau model pornografi. Jadi, catcalling bisa dianggap melanggar Undang-Undang karena catcalling menjadikan orang lain sebagai objek bagi pelakunya. 
Pasal 35 Undang-Undang No. 4 Tahun 2008 "Setiap orang yang menjadikan orang lain sebagai objek atau model yang mengandung muatan pornografi sebagaimana dimaksud dalam Pasal 9dipidana dengan pidana penjara paling singkat 1 (satu) tahun dan paling lama 12 (dua belas) tahun dan/atau pidana denda paling sedikit Rp500.000.000,00 (lima ratus juta rupiah) dan paling banyak Rp6.000.000.000,00 (enam miliar rupiah)" Pasal 35 dalam Undang-Undang No.4 tahun 2008 menjabarkan hukuman bagi mereka yang melanggar aturan yang tertulis dalam Pasal 9 Undang-Undang No.4. Mereka yang menjadikan orang lain sebagai objek pornografi dapat dikenakan pidana penjara paling singkat 1 (satu) tahun dan paling lama 12 tahun dan/atau pidana denda sebesar Rp. 500.000.000,- (lima ratus juta rupiah) sampai Rp. 6.000.000.000,- (enam miliar rupiah). Pujian atau sapaan bernuansa seksual, selama ini dianggap biasa saja. Padahal, perilaku semacam ini merupakan salah satu bentuk pelecehan. Catcalling merupakan bentuk pelecehan seksual di ruang publik, biasanya dilakukan di jalanan atau fasilitas umum lainnya. Ada pengaruh relasi kuasa pada perilaku catcalling. Pelaku merasa berada pada posisi superior sehingga berhak melakukan sesukanya tanpa mempertimbangkan perasaan orang lain. Pelakunya bisa siapa saja, baik laki-laki maupun perempuan, sendiri atau beramairamai.Catcalling juga dapat dialami siapa saja tanpa pandang jenis kelamin. Akan tetapi korban terbanyak adalah perempuan. Walaupun dalam keadaan tertentu laki-laki bisa saja menjadi korban catcalling, namun korban terbanyak perempuan.

Hal ini bukan karena disebabkan penampilan, di dalam beberapa kasus pelecehan verbal sebab dari pakaian atau penampilan korban kerap dijadikan alasan. Tetapi pandangan semacam ini adalah hal yang salah. Pada kasus catcalling yang dialami korban, yang mayoritas perempuan, dipandang sebagai objek seksual. Tubuh perempuan dipandang sebagai tubuh seksual yang membuat laki-laki tergoda. Salah satu contoh kasus catcalling yang banyak terjadi pada malam hari terhadap perempuan yang sendirian menunggu bus di halte. Ketika terjadi catcalling, korban justru disalahkan, pelecehan terjadi bukan karena penampilan atau apa yang dipakai korban, tetapi memang didasari dari niat dari si pelaku.

Pada tingkatan tertentu dampak catcalling dapat menimbulkan trauma berkepanjangan terhadap korbannya. Korban jadi membatasi mobilitasnya jika tidak ditemanisaat keluar rumah, yang pada akhirnya berdampak pada kualitas hidup dan menghambat perkembangan pribadinya. "Segala bentuk pelecehan seksual tak boleh 
dibiarkan, apalagi atasnama perbuatan iseng, bila kita ingin membangun masyarakat tanpa kekerasan". ${ }^{2}$

Pelecehan seksual secara verbal ini tidak hanya terjadi di Indonesia melainkan di negara lainnya. Pelecehan seksual secara verbal oleh beberapa negara, seperti Perancis, Argentina, Portugal,Belgia dan Peru telah ditanggapi secara serius karena berdampak besar pada kehidupan sosialmanusia dan psikologis korban. Negara tersebut menerapkan bukan hanya sanksi pidana tetapijuga sanksi denda kepada pelaku yang melakukan catcalling atau pelecehan seksual secara verbal. Pelecehan seksual secara verbal ini kian hari semakin meningkat karena adanya sebuah kecenderungan untuk dibiarkan dan tidak adanya kepastian hukum bagi korban. Catcalling dan street harassment sendiri merupakan fenomena yang jarang sekali diteliti, karena hal ini dianggap suatu perbuatan yang biasa di lingkungan masyarakat, padahal apabila diteliti lebih lanjut banyak korban merasakan ketidaknyamanan bahkan dampak yang ditimbulkan sangatlah berpengaruh bagi korban.

Tidak jarang kasus catcalling, dianggap sesuatu yang sangat di maklumi secara kultural bahkan dinormalisasi. Padahal seharusnya tindakan semacam itu bukanlah suatu hal yang wajar bagi objek catcalling, sehingga ini merupakan suatu perbuatan pidana dan harus dipertanggungjawabkan. Karena dampak dari catcalling sangatlah berpengaruh terhadap terganggunya psikologis bagiperempuan yang menjadi korban bahkan tidak jarang mengakibatkan terjadinya kekerasan psikologis. Kekerasan psikologis/ emosional adalah perbuatan yang mengakibatkan ketakutan, hilangnya rasa percaya diri,hilangnya kemampuan untuk bertindak, rasa tidak berdaya dan atau penderitaan psikis berat pada seseorang. Serta mengakibatkan timbulnya trauma bagi korban yang terkena catcalling bahkan perbuatan ini bisa terus terjadi dan tidak mendapatkan tanggapan dari masyarakat maupun penegak hukum. ${ }^{3}$

Perbuatan catcalling yang semakin sering terjadi, akan mengakibatkan dampak buruk bagi para korban. Hal ini dipengaruhi oleh beberpaa hal salah satunya adalah masih banyak korban yangtidak berani untuk melaporkan dan lebih memilih untuk diam. Banyak masyarkat yang melihat atau berada di sekitar tempat kejadian tidak banyak yang berani memberikan bantuan ataupun pembelaan terhadap korban catcalling karena takut akan berdampak pada keributan. Seiring dengan kemajuan jaman dan perkembangan teknologi informasi permasalahan terkait street harassment khususnnya catcalling tidak dapat dihindari akan

${ }^{2}$ https://www.kompas.com/tren/read/2021/02/08/060400765/apa-itu-catcalling-danmengapa-termasuk- pelecehan-seksual.

3 Yuni Kartika, Andi najemi, "Kebijakan Hukum Perbuatan Pelecehan Seksual (Catcalling) dalam Perspektif Hukum Pidana”, Journal Of Criminal Law, Vol. 1 No. 2, 2020, hlm. 4. 
semakin meningkat karena kemajuan teknologi akan membuat perubahan prilaku masyarakat.

Dalam sistem hukum Indonesia dan kebijakan hukum belum aturan hukum yang secara tegas mengatur terkait perbuatan catcalling itu sendiri hal ini dikarenakan catcalling pada awalnya adalah sebuah perbuatan yang dainggap biasa menjadi namun, pada perkembangannya perbuatan ini dapat dikategorikan sebagai perbuatan pidana. Karena jika dilihat dari prespektif hukum pidana perbuatan pelecehan seksual secara verbal (catcalling) diatur dalam Pasal 281 Ayat (2) Pasal 289, Kitab Undang-Undang Hukum Pidana, Pasal 8, Pasal 9, Pasal 34, Pasal 35 Undang-Undang Nomor 44 Tahun 2008 Tentang Pornografi. Pasal 281 Ayat (2) KUHP

"Barang siapa dengan sengaja dan di depan orang lain yang ada di situ bertentangan Dengan kehendaknya melanggar kesusilaan”.

\section{Pasal 289 KUHP}

"Barang siapa dengan kekerasan memaksa seseorang untuk melaatan cabul, diancam karena melakukan perbuatan yang Menyerang kehormatan kesusilaan, dengan pidana penjara paling lama sembilan Tahun".

\section{Pasal 8 UU NO. 44 Tahun 2008 Tentang Pornografi}

"Setiap orang dilarang dengan sengaja atau atas persetujuan dirinya menjadi objek atau model yang mengandung pronografi".

Pasal 9 UU NO. 44 Tahun 2008 Tentang Pornografi

"Setiap orang dilarang menjadikan orang lain sebagai objek atau model yang muatan pornografi".

Dengan adanya aturan hukum yang mengatur mengenai catcalling ini diharapkan dapat memberikan perlindungan hukum bagi korban dan memberikan hukuman yang setimpal bagi pelaku kejahatan catcalling (catcaller) sehingga menimbulkan efek jera dan terhadap masyarakat dapat lebih berhati- hati dalam bertindak karena prilaku catcalling dapat dijerat dengan hukuman pidana.

\section{KESIMPULAN}

Setiap manusia pada hakikatnya memiliki hak nya masing-masing untuk hidup bebas dan terhindar dari segala macam bentuk ancaman. Namun seiring berkembangnya zaman ancaman bisa datang dari siapapun, dimanapun, dan kapanpun. Ancaman tersebut bisa

\footnotetext{
${ }^{4}$ Yuni Kartika, Andi najemi, Op.Cit, hlm. 6
} 
berupa apa saja termasuk pelecehan seksual. Manusia sebagai mahluk sosial sangat membutuhkan interaksi dengan orang lain atau biasa kita kenal dengan istilah interaksi sosial. Namun, di dalam interaksi sosial seringkali terjadi penyimpangan yang menimbulkan perselisihan antar individu yang sedang berinteraksi, hal ini sesuai dengan Teori Perspektif Prilaku yang pada intinya didalam suatu interaksi munculah suatu respon atau tanggapan yang tidak selalu positif, adakalanya itu berubah menjadi negatif.

Hal tersebut didasari pada perasaan seseorang yang sedang berinteraksi, yang terkadang menyinggung perasaan atau menunjukan prilaku yang seharusnya tidak dilakukan. Pada perbuatan catcalling hal ini dapat berupa suatu ucapan, komentar, siulan, atau pujian, ataupun kedipan mata sehingga membuat seseorang merasa tidak nyaman dan cenderung merasa terancam. Hal tersebut lumrah terjadi pada masyarakat karena ketidaktahuannya masyarakat terkait catcalling yang menganggap hal-hal seperti itu biasa saja terutama saat sedang diperjalanan, dipasar, dan tempat umum lainnya.

Padahal hal tersebut sangat berdampak kepada korban sehingga melahirkan perasaan takut. Upaya penegakan hukum di Indonesia mengenai perilaku catcalling masih cenderung rendah hal ini disebabkan oleh beberapa faktor yakni faktor hukum yang tidak langsung mengatur mengenai catcalling, faktor aparat penegak hukum yang berbeda pemahaman mengenai pelecehan secara verbal, faktor masyarakat dengan istilah catcalling inimasih jarang di dengar sehingga jika terjadi pelecehan si korban cenderung tidak berani untukmelaporkannya. Perlindungan hukum bagi para korban pelecehan seksual secara verbal catcalling dapat dilakukan melalui hak-hak yang tertuang dalam Pasal 5 UndangUndang Nomor 31 Tahun 2014 Tentang Perubahan Atas Undang-Undang Nomor 13 Tahun 2006 Tentang Perlindungan Saksi dan Korban, Undang-Undang Nomor 39 Tahun 1999 Tentang HakAsasi Manusia.

\section{SARAN}

Pemerintah perlu membuat peraturan hukum yang mengatur secara langsung atau spesifik terkait perbuatan catcalling sehingga perlindungan hukum terhadap korban dari catcalling ini dapat dimaksimalkan sehingga upaya penanggulangan kasus kekerasan seksual khususnya catcalling dapat berjalan dengan baik. Selain itu perlu adanya upaya preventif yang dilakukan oleh pemerintah berupa kegiatan sosialisasi guna menumbuhkan kesadaran masyarakat terhadap catcalling. Upaya penegakan hukum terhadap pelaku pelecehanseksual secara verbal harusnya dijalankan sesuai dengan aturan hukum guna memberikan kepastian hukum serta perlindungan terhadap korban. 


\section{DAFTAR PUSTAKA}

\section{A. Buku}

Zaidan, M. Ali. 2016. Kebijakan Kriminal. Sinar Grafika. Jakarta.

Arief, Barda Nawawi. 1996. Bunga Rampai Kebijakan Hukum Pidana. PT. Citra Aditya Bakti, Bandung,

Pardede, Rudi. Proses Pengembalian Kerugian Negara Akibat Korupsi. Genta Publishing. Yogyakarta.

\section{B. Jurnal}

Djokowidodo. Agustinus dan Wenny Wijayanti 2019. "Persepsi Peserta Didik Terhadap Kekerasan Verbal" oleh Guru di SMP se-Kota Madiun, Vol 2, Nomor 2 November 2019.

Najemi. Andi dan Yuni Kartika. 2020. "Kebijakan Hukum Perbuatan Pelecehan Seksual (Catcalling) dalam Perspektif Hukum Pidana" Journal of Criminal Law. Vol. 1 No.2

Mustafa, Hasan. 2012. Perilaku Manusia dalam Perspektif Psikologi Sosial. Jurnal Administrasi Bisnis (2011), Vol.7, No.2: hal. 143-156, (ISSN:0216-1249). 2011 Center for Business Studies. FISIP - Unpar.

\section{Peraturan Perundang-Undangan}

Undang-Undang Dasar Negara Republik Indonesia Tahun 1945Kitab Undang-Undang Hukum Pidana (KUHP)

Undang-Undang nomor 1 tahun 1946 tentang Peraturan Hukum Pidana

Undang-Undang Nomor 39 Tahun 1991 tentang Hak Asasi Manusia, Tambahan Lembaran Negara Republik Indonesia Nomor 3886

Undang-Undang Nomor 44 Tahun 2008 Tentang Pornografi Tambahan Lembaran Negara Nomor 4928

Undang-Undang Nomor 31 Tahun 2014 Tentang Perubahan Atas Undang-Undang UndangUndang 13 Tahun 2006 Tentang Perlindungan Saksi Dan Korban Tambahan Lembaran Negara Tahun 2014 Nomor 293

\section{Internet}

https://www.kompas.com/tren/read/2021/02/08/060400765/apa-itu-catcallingdan-mengapa-termasuk-pelecehan-seksual.

https://www.google.com/amp/s/wartakota.tribunnews.com/amp/2019/09/08/vira l-polisi-tangkap-pelaku-catcalling-di-lampu-merah-korban-dan-pelakupelecehan-verbal- berdamai. 